\title{
The Investigation of Pre-service Science Teachers' Opinions on Some of the Biology and Biotechnology Concepts
}

\section{Fatma Gülay Kırbaşlar}

Prof. Dr., İstanbul University, Hasan Ali Yücel Education Faculty, Department of Science Education Vefa, 34070, İstanbul, Turkey; Email: gkirbas@istanbul.edu.tr

Çiğdem Çıngıl Barış

Assist. Prof. Dr., İstanbul University, Hasan Ali Yücel Education Faculty, Department of Science Education Vefa, 34070, İstanbul, Turkey; Email: ccingil@istanbul.edu.tr

\section{Doi:10.5901/jesr.2016.v6n1p9}

\section{Abstract}

\begin{abstract}
Today, it is seen rapid progress in some areas such as biotechnology. Since determination of the DNA structure, advances in biology, biotechnology and genetic engineering have emerged very fast and on such a great scale that teachers should be able to adapt to new developments. Teacher education has an important task to prepare students for their coming professions. The objective of this study was to find out pre-service science teachers' conceptions on biology, biotechnology, genetically modified (GM) food and their ideas on teaching and assessment strategies to help their students' understanding of these technologies. The participants were 150 pre-service science teacher in Turkey. A questionnaire contains eight closed-ended and four openended items were used to determine pre-service science teachers' perceptions of biology and biotechnology issues. Quantitative and qualitative methodologies were used to analyze data. As a result of this research, it was observed that preservice science teachers does not have sufficient knowledge or their information that is contradictory.
\end{abstract}

Keywords: Pre-service science teacher, Biology education, Biotechnology education, Genetically modified product.

\section{Introduction}

Biotechnology has made advancement quickly throughout the world, the attitudes of people towards it in our time is a different manner. Studies show that most countries promote education, applications and researches on this issue. Biotechnology has obtained increasing significance in our country. It is extensively accepted that biotechnology is one of the most promising and innovative technology in the $21^{\text {st }}$ century. Biotechnology is an issue in the agenda in both political and academical circles for its effects on food safety, economic growth and distribution of income, human health, the environment, and agribusiness in these days. Genetic modification techniques are located in the center of this focus and have gave rise to discussion on biosafety topics. These new techniques is seen as a potential threat to the environment, to human life and to present plant and animal species.

These concerns have resulted in government regulations that have tightened surveillance, inspection, and investigation control and genetically modified (GM) varieties commercialization, specially GM foods in some countries (Zhong et al., 2002). The discovery of the molecular structure of DNA in 1953 by Watson and Crick launched in a new period. Studies in genetics conducted after this discovery has enlighten many mysteries in life (Kılıç and Sağlam, 2014). Modern biotechnology including a lot of areas such as medicine, pharmacy and biology is of increasing interest in Turkey as well as other places in the world.

Biotechnology is a great area for students to understand the heredity, agriculture and critically evaluate the benefits and risks of this new technology. Promoting scientific literacy among all learners is a main target of science education. Person who is scientifically literate on biotechnology can compare the processes of selective breeding and transgenic regulation of plants, debate the arguments for and against genetic modification of foods, describe the possible future influence of genetically modified foods, analyze public opinion about the use and safety of genetically modified foods (Dawson and Schibeci, 2003). In many researchers have also shown that biotechnology is one of the most significant and difficult subjects in science to learn (Kindfield, 1991; Bahar, Johnstone and Hansell, 1999; Banet and Ayuso, 2000; Duncan and Reiser, 2007; Smith and Williams, 2007; Dogru-Atay and Tekkaya, 2008; Yilmaz, Tekkaya and 
Sungur, 2011). Teachers are important role to help their students become a scientifically literate. Teachers' knowledge on some concepts about biology and biotechnology especially GM foods and GM medicines risks and benefits of these technologies associated with their use is important. Teachers should know how to teach biology and biotechnology effectively in order to help students understand the subject and create an effective learning environment. A teacher cannot be expected to teach what he/she does not understand. So, training programs should focus on improving science teachers' conceptions of the new technological development like as biology and biotechnology with the anticipation that their own students' knowledge on the issue would improve (Hurd, 1998).

Students can understand the importance of biotechnology in daily life with biotechnology training in school years from elementary school to college level and they can understand how biotechnology could help to solve major world problems such food and energy shortages as well as environmental issues. In addition, students are trained in biotechnology especially in biology courses can give the idea of in their future career selections to work and continue their educations in biotechnology areas such as genetic engineering (Türkmen and Darçın, 2007).

Biotechnology educational programs and models are important for the development for science teachers and students as well as good programs and teaching strategies that uses science and biology teachers in the right diverts concepts of biotechnology is extremely important (Dunham et al., 2002). It is important to know how people and students perceive and understand biotechnology and what are the misconceptions related to biotechnology. In this regard, biotechnology education gains significance because the misinformation about biotechnology and negative attitudes toward biotechnology could only be changed through science and science education. Additionally it should be remembered that especially science teachers have an important responsibility to give the importance of biotechnology in our lives and the right biotechnological knowledge to their students (Harms, 2002).

The aim of the studies on the biology and biotechnology education to reveal the causes of failures. The most important of reasons, most students' understanding of the concepts wrong in biology. In this situation, students' understanding of both the available information and makes it difficult to advance their knowledge further. In recent years, advances in genetics, draws attention to the importance of this science. In some countries, new methods and techniques have focused on putting out to provide better learning studies students of such as gene, DNA and chromosome concepts. However, few studies of this type in our country. Therefore, such as gene, DNA and chromosome concepts what students know and do not know, or how wrong they knew better than to learn these concepts should be investigated. Bahar et al. (1999) and Lewis \& Wood-Robinson (2000) on the high school and college students and Tekkaya et al. (2000)'s high school graduates in their work, on the problematic issues related to cell division and genetics, and biology curriculum is inadequate understanding of the issues underlying this case has created difficulty for learning other subjects have suggested that.

The unrealized conceptual learning is seen as a problem for all academic levels. Especially when it comes to teacher candidates, to give priority to resolving this situation is becoming a problem. The reason for this is the future of science teachers has misconceptions, is that they affect by means of a large number of students. One of the most important elements of the educational process, teachers are the ones primarily responsible for classroom teachinglearning activities. For this reason, the teachers use modern teaching methods and technology, to increase the education quality is of great significance in terms of (Reis, 2004).

The aim of this study, to take the views of pre-service science teachers on the available information on some biology and biotechnology concepts.

\section{Method}

\subsection{Research Model}

Both quantitative and qualitative research methods were used in this research. A questionnaire contains 8 closed-ended and 4 open-ended items was applied for pre-service science teachers to get their views on biology and biotechnology concepts.

\subsection{Sampling}

The sample of this study is formed by the 150 pre-service science teachers at the Faculty of Education, Department of Science Education in Turkey. The questionnaire was prepared within the scope of the study was applied to n: 101 (67.3\%) female and n: 49 (32.7\%) male pre-service science teachers. 


\subsection{Data Collection Instruments and Data Analysis}

A questionnaire contains 8 closed-ended and 4 open-ended items was applied. Items have been prepared to take on the information and opinions with chromosome, relations between genes and DNA, the concept of GM Organism (GMO) and GM products. For questions' validity and the answers characterization were consulted by expert opinions and created by considering feedback.

Quantitative and qualitative research methods were used to evaluate the data. Evaluation of closed-ended questionnaire conducted with SPSS 13.0 software and chi-square test were used. The evaluation of responses to openended questions of content analysis was applied. Analysis was carried out in four steps as shown below (Yıldırım and Şimşek, 2008):

1. The Coding: Examining the data obtained, it tries to separated into meaningful sections. In this section, sometimes a word, a sentence or paragraph may sometimes give a page. All constitute in itself a significant portion are combined, named, by the researcher, is encoded in other words.

2. The Themes (Category) Finding: The codes are combined and analyzed. To find commonalities among the codes are studied. The collected data are categorized by means of codes.

3. Code and Regulation of Theme: Organizes data collected by researchers in the third stage.

4. Identification and Interpretation of Results: In the final stage the data is interpreted by the researcher.

\section{Results}

\subsection{Results of the First Stage:}

Pre-service science teachers' responses to closed-ended survey items results are as follows:

$97.3 \%$ of the research group are participated in the idea of "GM products are not natural", $2.7 \%$ of group stated that no information on this subject. The item of GMO means "genetically modified organism" in the group of people are responded that, yes $85.3 \%, 1.3 \%$ no, $13.3 \%$ I do not know. 33.3\% of the research group are participated in the idea of "GM products are hormone-added", $42.0 \%$ of group do not agree and $24.7 \%$ of group stated that no information on this subject. Item that measures whether knowledge about GM product, $16.7 \%$ of the research group have no knowledge, $78.0 \%$ that I know, $5.3 \%$ were found to be undecided about whether or not the owner of the information. $10.0 \%$ of the research group participated in the idea of "GM products are safe", $82.7 \%$ are disagreed, $7.3 \%$ of group stated that no information is. $42.0 \%$ of the research group is thinking of GM products are carcinogenic, $11.3 \%$ of group stated that disagreed with this statement. However, $46.7 \%$ of the research group, stated that not the knowledge on this subject. While $74.0 \%$ of the research group are participated in the idea of "It is possible to understand the external appearance of GM products", $1.3 \%$ of the group not participating in this idea. However, $24.7 \%$ of the research group, stated that not the knowledge on this subject. $2.0 \%$ of the research group are participated in the idea of "GM products can only be recognized by DNA analysis", $98.0 \%$ of group stated that no information (Fig. 1).

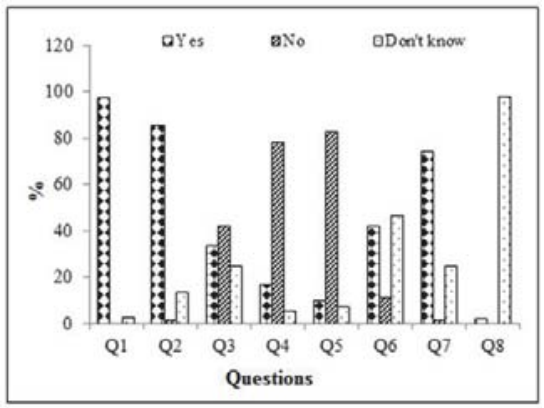

Figure 1. Pre-service science teachers' responses to closed-ended items (Q1. GM products are not natural. Q2. GMO means Genetically Modified Organisms. Q3. GMO is hormone added products. Q4. I do not have detailed information about GM products. Q5. GM products are safe. Q6. GM products are carcinogenic. Q7. GM products understood by external appearance. Q8. GM products only understood by DNA analysis.). 
Table 1. Results of Chi-Square Test Performed to Determine Dependency Between of 'Gender' and 'GM products are safe' Opinions.

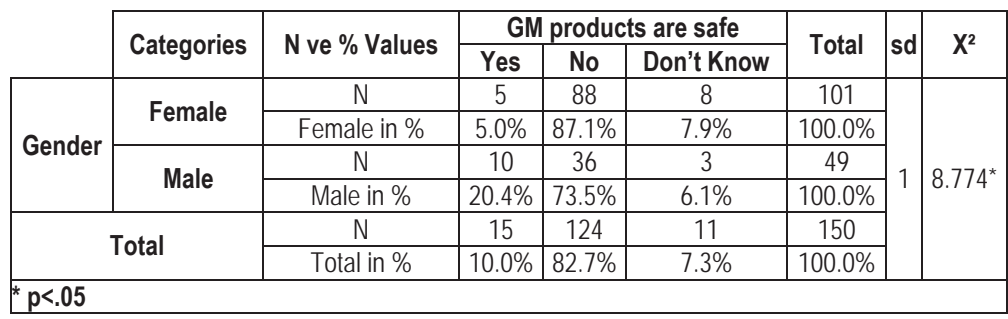

As seen in Table 1, while $87.1 \%$ of girls in the group that make up the survey sampling stated they did not agree with the statement that "GM products are safe" $73.5 \%$ of boys do not agree with this statement. The difference between these two variables has been found statistically meaningful $\left(X^{2}=8.774 ; p<.05\right)$.

Table 2. Results of Chi-Square Test Performed to Determine Dependency Between of 'Gender' and 'GM products are carcinogenic' Opinions.

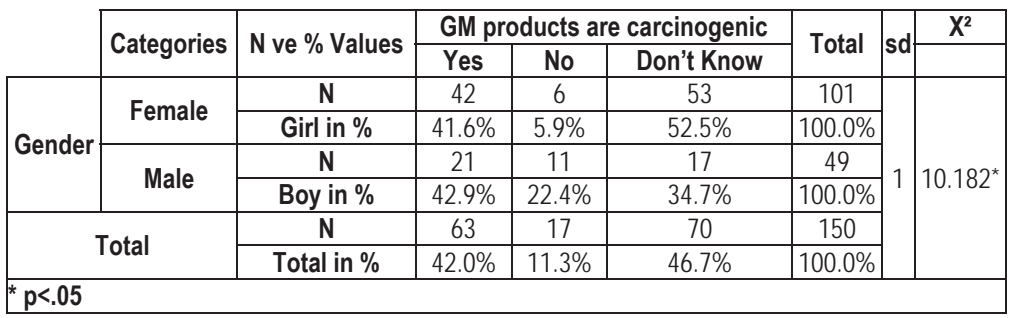

In Table 2, while $52.5 \%$ of girls in the sampling survey, stated they had no idea about the statement "GM products are carcinogenic", $41.6 \%$ of them said "yes" to this statement. $42.9 \%$ of boys in the group agrees with this statement. The difference between these two variables has been found statistically meaningful $\left(X^{2}=10.182 ; p<.05\right)$.

Table 3. Results of Chi-Square Test Performed to Determine Dependency Between Opinions of 'GM products are carcinogenic' and 'GM products are hormone-added'.

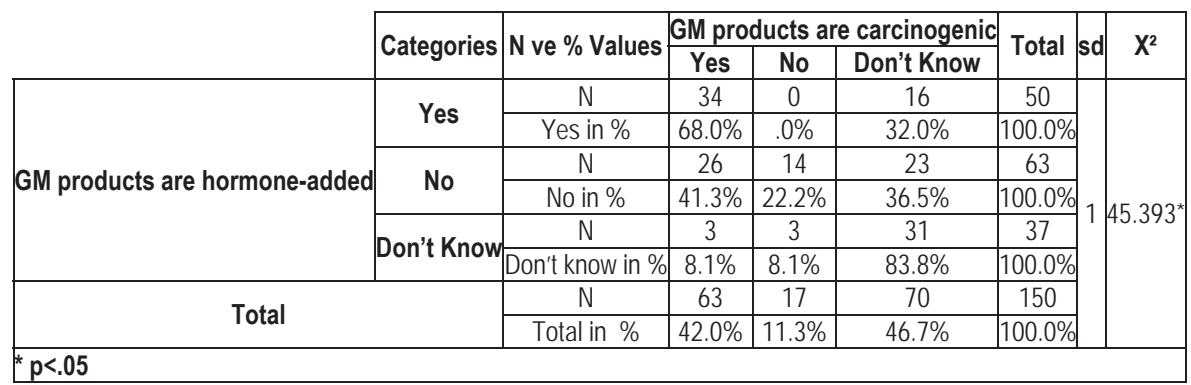

In Table 3, while $68 \%$ of the survey sampling agreed with the expression that "GM products are hormone-added" and "GM products are carcinogenic." $83.8 \%$ of them stated they had no idea about these two statements. The difference between these two variables has been found statistically meaningful $\left(X^{2}=45.393 ; p<.05\right)$. 
Table 4. Results of Chi-Square Test Performed to Determine Dependency Between Opinions of 'I don't know about GMO" and 'GM products are safe'.

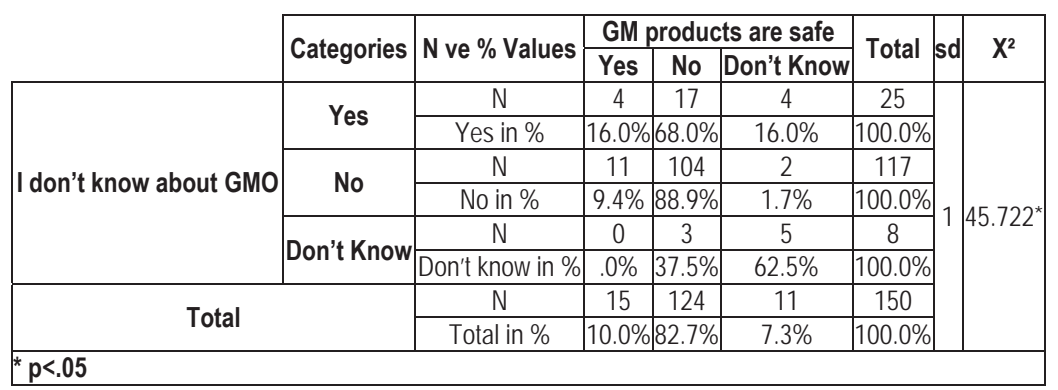

As seen in Table 4, 104 participants (88.9\%) who disagreed with "I do not know about GMO" said also 'no' for "GM products are safe". The difference between two variables were found statistically significant $\left(X^{2}=45.722 ; p<.05\right)$.

Table 5. Results of Chi-Square Test Performed to Determine Dependency Between Opinions of 'GM products are carcinogenic' and 'It is possible to understand the appearance of GM products'.

\begin{tabular}{|c|c|c|c|c|c|c|c|c|}
\hline & \multirow[t]{2}{*}{ Categories } & \multirow[t]{2}{*}{$\mathrm{N}$ ve $\%$ Values } & \multicolumn{3}{|c|}{$\begin{array}{l}\text { It is possible to understand the } \\
\text { appearance of GM products }\end{array}$} & \multirow[t]{2}{*}{ Total } & \multirow[t]{2}{*}{ sd } & \multirow[t]{2}{*}{$X^{2}$} \\
\hline & & & Yes & No & Don't Know & & & \\
\hline \multirow{6}{*}{$\begin{array}{l}\text { GM products are } \\
\text { carcinogenic }\end{array}$} & \multirow{2}{*}{ Yes } & $\mathrm{N}$ & 55 & 0 & 8 & 63 & \multirow{8}{*}{1} & \multirow{8}{*}{$14.914^{*}$} \\
\hline & & Yes in \% & $87.3 \%$ & $.0 \%$ & $12.7 \%$ & $100.0 \%$ & & \\
\hline & \multirow{2}{*}{ No } & $\mathrm{N}$ & 13 & 1 & 3 & 17 & & \\
\hline & & No in $\%$ & $76.5 \%$ & $5.9 \%$ & $17.6 \%$ & $100.0 \%$ & & \\
\hline & \multirow[b]{2}{*}{ Don't Know } & $\mathrm{N}$ & 43 & 1 & 26 & 70 & & \\
\hline & & $\begin{array}{c}\text { Don't know in } \\
\%\end{array}$ & $61.4 \%$ & $1.4 \%$ & $37.1 \%$ & $100.0 \%$ & & \\
\hline \multirow{2}{*}{\multicolumn{2}{|c|}{ Total }} & $\mathrm{N}$ & 111 & 2 & 37 & 150 & & \\
\hline & & Total in \% & $74.0 \%$ & $1.3 \%$ & $24.7 \%$ & $100.0 \%$ & & \\
\hline
\end{tabular}

As seen in Table 5, 55 participants (87.3\%) who disagreed with "GM products are carcinogenic" said also 'yes' for "It is possible to understand the appearance of GM products". The difference between two variables were found statistically significant $\left(X^{2}=14.914 ; p<.05\right)$.

\subsection{Results of the Second Stage:}

The responses of each student's open-ended items are grouped under specific headings. Similar answers are put together and five main headings for the first and the second items, seven main headings for the third item, and five main headings for last item are formed. The pre-service science teachers' responses to open-ended items are as follows:

$54.57 \%$ of the research group has stated they have derived their knowledge about genetically modified (GM) product from media. $15.17 \%$ of the participants has said they have derived knowledge by means of only personal curiosity, $9.67 \%$ in (high school) genetics classes, $6.17 \%$ from their friends, while $14.42 \%$ has left the item unanswered.

About the relation between GM product, DNA and genes, of participant teachers; $40.1 \%$ have stated there is a relation between natural state-gene-DNA, 9.0\% has stated, genes change when a change has been made in DNA, $13.1 \%$ has said chromosome-gene-DNA, $9.0 \%$ has stated there is a hormone-gene-DNA relation, $28.8 \%$ left unanswered.

About the statement whether to eat GM products or not, of the participants who said they will not eat GM products; $43.37 \%$ said because these products are not natural, $7.87 \%$ has stated because it is chemically modified and carcinogenic, $7.87 \%$ has stated because they can have long term hazardous affects, $3.4 \%$ has stated because such products are commercial, they are not healthy, $18.47 \%$ because they think the DNA of these products are changed with 
hormone-added and $9.44 \%$ has stated they might eat, $5.4 \%$ has stated they are indecisive. Other interesting answers by students are as such:

No I would not eat, because vegetables and fruits which grow earlier than its season might contain hazardous materials.

They might disturb ecosystem in the future.

They ripen the products before its season.

Their genes are not proper.

They disturb the body's order.

They are carcinogenic, and their nature has been changed by adding various ingredients, I never eat.

As a sampling for GM products, $40.2 \%$ of participant teachers has said I would show GM and non-GM product together, $10.8 \%$ has said I would put hormones and hormone-free vegetable and fruit samples side by side, $8.0 \%$ has said, I would find GM product images from the internet, 14.3\% has said they would not be able to show any sample. Other interesting answers by students are as follows: Square watermelon, giant strawberry, coloured flowers, big tomatoes, strawberry and cucumber; a fruit produced as seedless while originally possesses seeds, seedless fruit, blue rose; black apple and seedless tomato; food that looks and tastes different; I would bring, GM and non-GM fruits and get them taste, sterile and seedless tomatoes; featherless chicken whose DNA has been changed; giant tomatoes, corn; soy bean; tomatoes; seedless fruit and giant watermelon (Fig. 2).

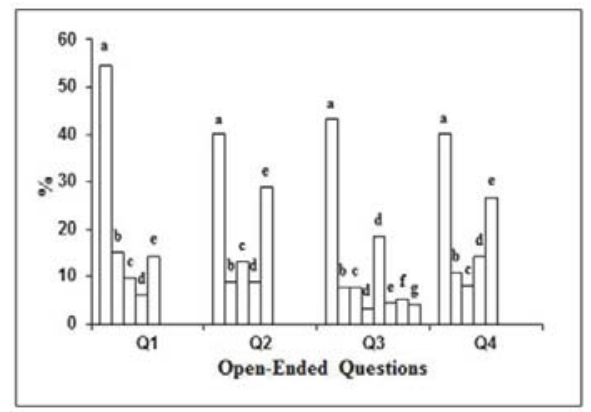

Figure 2. The analysis of open-ended part of questionnaire (Q1a: Media, b: Curiosity, c: Genetics classes, d: Friends, e: Unanswered; Q2a: Natural state-gene-DNA, b: Genes change, c: Chromosome-gene-DNA, d: Hormone-gene-DNA, e: Unanswered; Q3a: They do not eat, b: Carcinogenic, c: Hazardous effects, d: Commercial, e: Hormone added, f: They might eat, g: Indecisive; Q4a: GM and non-GM product together, b: Hormones and hormone-free samples, c: GM product images from the internet, $d$ : They would not be able to show any sample, e: Other).

\section{Discussion}

According to the analysis of closed-ended questionnaire, almost all of science teacher participants have stated GMO letters means Genetically Modified Organism (85.3\%) and that these products are not natural (97.3\%), and they must have thought that this also means to have detailed knowledge about the issue, as they $78 \%$ of the participants have stated they have detailed knowledge about the issue. The ideas they state, however, proves that they are wrong in this assumption. Because $33 \%$ of the participants stated GM products are hormone added, only $42 \%$ of them have stated they do not agree with this idea, and $24.7 \%$ have stated they do not have an idea. We can assume more than half of the participants (58\%) do not know what GM products mean. $42 \%$ of the participants has stated GM products are carcinogenic, $11.3 \%$ stated they do not agree, $46.7 \%$ stated they do not know. While almost half of the participants stated, they do not know if these products are carcinogenic, $82.7 \%$ have stated these products are not trustable, reflecting that they have a prejudiced approach to these products. $74.0 \%$ of the participants has stated these products can be determined by their appearance, pointing out that they think these products will definitely have visuality. Almost all of the pre-service science teachers (98\%) said they do not know as to whether these products can only be recognized by DNA analysis. As most of the participants already said these products can be recognized by means of visuality, to choose "I do not know" option instead of "no" shows a contradiction and indecisiveness in their ideas. 
According to the answers the participants give to open-ended items approximately half of the participants (54.57\%) have stated they derived their knowledge about GM products from media and they have not taken into consideration their school-based knowledge. This shows the teacher participants did not graduate from high school with sufficient knowledge. While according to Dawson \& Soames (2006) for most students over 8 age, school is the main source of their knowledge about biotechnology, Dawson and Schibeci (2003) pointed out, most students graduate from secondary school with very little knowledge about biotechnology, cloning and GM products. To the item about DNA and gene relation $40.1 \%$ of the students said natural structure, $9.0 \%$ any change in DNA causes gene change, $13.1 \%$ chromosome gene, $9.0 \%$ hormone-gene-DNA, and $28.8 \%$ left the item unanswered. We can conclude half of the participants assume gene and DNA relationship make up genetic speciality and natural structure; we can also conclude the other half think differently and have no idea. $43.37 \%$ of the participants said they would not eat GM products because they are not natural, other participants in smaller proportions stated various reasons such as; because they are carcinogenic, because its chemistry has been changed, because they are hormone added, because it's DNA has been changed by adding hormone, because chemicals are added, because they are not trustable in the long term and because they are commercial. However $9.44 \%$ percent of the pre-service science teachers stated that they could eat. The results of the survey indicated that pre-service science teachers recognize the relationship between DNA and gene mean to genetic material and when they face to GM products they know these products have genetically modified materials. Nevertheless other participants affirmed that they would not eat hence the idea of modifications shatter the naturality of the products and unnatural foods are harmful to health. According to the results of research of Özel et al. (2009) conducted with high school students indicated that; $53 \%$ of participants stated that they do not know what the genetic engineering will bring in the future, $69 \%$ did not perceive GM products as healthy and 51\% thought genetically modified organisms contains highly hazardous chemicals.

About sampling a GM product, almost half of the participants (40.2\%) said they would show GM and non-GM fruit and vegetable samples together, $10.7 \%$ would show non-hormone and hormone added fruit and vegetable samples together, $8 \%$ would show an image of a GM product, $14.3 \%$ however, stated they would not be able to show an example. Other participants gave different answers, such us; square watermelon, seedless and sterile tomato, featherless chicken, corn, soybean, blue rose, black apple. We can conclude only $25 \%$ of the participants made right sampling. In a research of Lock and Miles (1993) made with high school students, almost half of the group expressed they do not know what biotechnology and genetic engineering mean, and they cannot give an example for the subject. In the same way, in a research Chen and Raffan (1999), it was concluded that the participants cannot give an example for biotechnology and genetic engineering, Dawson and Schibeci (2003) concluded approximately $20-30 \%$ of the high school students cannot give an example for genetic engineering, biotechnology, cloning and GM products.

The fact that most participant teachers think GM products can be recognized by their appearance, can be because these products are confused with huge hormone added products. Because most participants, gave tomatoes or strawberries bigger than their natural size as an example to GM or non-GM fruit or vegetable, a smaller proportion gave hormone added fruit and vegetable as an example. The participants, who stated these products can be recognized by their appearance, might have thought this relation in the same way as hormone and size relationship.

\section{Conclusion}

Consequently, in this research it has been found out that the notion GM products and hormone added products are confused with each other. In the research of Özel et al. (2009), 68\% of the participants, stated genetically modified organisms are always bigger. While $98 \%$ of them said "I do not know" to the item whether GM products can be defined by DNA analysis instead of saying "no", shows they both lack the adequate knowledge, and their ideas are contradictory.

\section{References}

Bahar, M., Johnstone, A. H., \& Hansell, M. H. (1999). Revisiting learning difficulties in biology. J. of Biological Education 33 (2): $84-86$.

Banet, E., \& Ayuso, E. (2000). "Teaching Genetics at Secondary School: A Strategy for Teaching about the Location of Inheritance Information." Science Education.84: 313-351.

Chen, S. Y., \& Raffan, J. (1999). Biotechnology: Student's knowledge and attitudes in the UK and Taiwan. Journal of Biological Education, 34(1): 17-23.

Dawson, V., \& Schibeci, R. (2003). Western Australian school students' understanding of biotechnology. International Journal of Science Education. 25 (1): 57-69.

Dawson, V. M., \& Soames, C. (2006). The effect of biotechnology education on secondary school students' understandings and 
attitudes about biotechnology processes. Research in Science and Technological Education, 24(2), 183-198.

Dogru-Atay, P., \& Tekkaya, C. (2008). "Promoting Students' Learning in Genetics with the Learning Cycle." Journal of Experimental Education. 76: 259-280.

Duncan, R. G., \& Reiser, B. J. (2007). "Reasoning across Ontologically Distinct Levels: Students' Understanding of Molecular Genetics." Journal of Research in Science Teaching. 44: 938-959.

Dunham, J., Wells, J., \& White, K. (2002). Photobioreactor: biotechnology for the technology education classroom. The Technology Teacher, October, 7-12.

Harms, U. (2002). Biotechnology education in schools. Electronic Journal of Biotechnology. 15(3). Retrieved 11 November 2014 from Internet http://www.ejbiotechnology.info/content/vol5/issue3/teaching/01/index.html.

Hurd, P. (1998). Scientific literacy: what could it mean?. Science Education. 82(3): 402-416.

Kılıç, D., \& Sağlam, N. (2014). Students' Understanding of Genetics Concepts: The Effect of Reasoning Ability and Learning Approaches, Journal of Biological Education. Vol. 48, No. 2: 63-70.

Kindfield, A. C. H. (1991). "Confusing Chromosome Number and Structure: A Common Student Error." Journal of Biological Education. 25: 93-200.

Lewis, J., \& Wood-Robinson, C. (2000). Genes, chromosomes, cell division and inheritance-do students see any relationship? International Journal of Science Education. 22(2): 177-195.

Lock, R., \& Miles, C. (1993). Biotechnology and Genetic Engineering: Students' Knowledge and Attitudes. Journal of Biological Education. 27(4): 267-273.

Ozel, M., Erdogan, M., Usak, M., \& Prokop, P. (2009). High school students' knowledge and attitudes regarding biotechnology applications. Educational Sciences: Theory \& Practice. 9(1): 297-328.

Reis, Z. A. (2004). Bilgisayar destekli öğrenme-öğretme sürecinde teknoloji ve yardımcı materyallerin kullanımı. IV. International Education Technologies Conference. 24-26 Kasım Sakarya, 1, 154-159.

Smith, L. A., \& Williams, J. M. (2007). "It's the X and Y Thing": Cross-Sectional and Longitudinal Changes in Children's Understanding of Genes." Research in Science Education. 37: 407-422.

Tekkaya, C., Özkan, Ö., Sungur, S., \& Uzuntiryaki, E. (2000), Öğrencilerin Biyoloji Konularını Anlama Zorlukları. IV.Fen Bil. Eğt. Kongresi Bildirileri. Ankara.

Türkmen, L., \& Darçın,. E. S. (2007). A comparative study of Turkish elementary and science education major students' knowledge levels at the popular biotechnological issues. International Journal of Environmental and Science Education. 2 (4): 125-131.

Yilmaz, D., Tekkaya, C., \& Sungur, S. (2011). "The Comparative Effects of Prediction/Discussion-Based Learning Cycle, Conceptual Change Text, and Traditional Instructions on Student Understanding of Genetics." International Journal of Science Education. 33: 607-628.

Zhong, F., Marchant, M. A., Ding, Y., \& Lu, K. (2002). GM foods: A Nanjing case study of Chinese consumers' awareness and potential attitudes. AgBio Forum. 5 (4): 136-144. 